\title{
Religion and Economics: From the Transformation of the Human Capital Index (HCI) to the Economic Sovereignty of Islamic Boarding Schools in Indonesia
}

\author{
Dede Aji Mardani ${ }^{\mathrm{a},{ }^{,},}$, Rifki Rosyad ${ }^{\mathrm{b}}$ \\ ${ }^{a}$ Department of Sharia Economics, STAI Tasikmalaya, Indonesia \\ ${ }^{b}$ Faculty of Ushuluddin, UIN Sunan Gunung Djati Bandung, Bandung, Indonesia
}

\begin{abstract}
The purpose of this study is to analyze the role of the boarding school leadership in improving the quality of human resources as a whole. The contribution of human resources is very important in the progress of this boarding school. The method used is through a phenomenological approach, in which the researcher is directly involved in the struggle of society and the students directly. Researchers observe and analyze and interview the parties who are directly related. The success of building a nation, starting from the development of human resources, HCL (Human Capital Index) plays a very important role in the development of civilization towards SGDs. The HCL component, which includes education, health and social security, has been implemented in the Idrisyah Islamic boarding school, as a Tarekat. The application of the HCL principles greatly impacts on sustainable human development. Tarekat in Indonesia that apply it because they still apply spirituality of worship vertically, the majority do not have an impact on socio-culture, economy, development and others and as a result unemployment, poverty is not significantly reduced. This tarekat is a new trend in socio-societal change and as a Sufistic movement in Indonesia.
\end{abstract}

Keywords: Human Capital Index, Tarekat Idisiyah, Transformasion.

\section{Introduction}

Improving the quality of human resources begins with education, apart from the dualism of education as a basis. Education with the Islamic boarding school model has a distinctive style (Jahar, 2015; Saepudin, 2019). Recently, the development of education and human civilization has experienced tremendous leaps and bounds. The world of disruption has spread to various layers of life, including in religious matters(Dillon, 2009; Smith, 1996; Ying et al., 2017), according to him this is caused by economic factors, geography, transcendent motivation, organizational resources, divided identity, privilege, social and geographical position, self-interest. and institutional.

This fact has been going on for a long time and will continue to undergo inconsistent changes. As part of administering religious education in Islamic boarding schools, it must be able to improve the quality of human resources (HR) with the curriculum that it runs, so the forms of education implanted in Islamic boarding schools have different varieties.

The form of curriculum development being taught must be able to answer global challenges and problems, such as being sensitive to the environment, which has been implemented in the Nurul Haramain Narmada Islamic boarding school in West Lombok which emphasizes education that cares about ecology (Efendi et al., 2019). Even so, there are many more innovative curriculum and learning models in Islamic boarding schools. That the Islamic boarding school not only focuses on ansich's spiritual education, but also cares for environmental preservation, empowerment of

\footnotetext{
* Corresponding author.

E-mail address: dedeaji.m@gmail.com (Dede Aji Mardani)
} 
students, utilization of agricultural land and fields, mastery of science and technology, fisheries that can lead to future economic growth and resilience. Curriculum changes will have an impact if it is started from the manager or leader of the boarding school.

Boarding school leaders have an obligation to bring their students into a life full of competition and adapt to technology (Manan, 2019). The Idrisiyah boarding school relies on the authorization of its leaders in all aspects. The murshid plays a major role in controlling the tarekah and business(Dede Aji Mardani, 2019). Including the leadership of the boarding school has a role in preventing radicalism or even directing resistance to the legitimate government (Bahri, 2018). The leadership has a very important responsibility in bringing a new flow of students to face the new era.

The fact is that the leadership characteristics differ according to the region, descent, and customs where the ponpos is located. There has been a change in leadership from an individual and kinship nature to collective leadership (Ilyas et al., 2019). This assumption is fundamental because the position of the boarding school has transformed itself to open itself in the management of its management. History has recorded that the position of the Indonesian nation was occupied by people who had studied at Islamic boarding schools. The education he taught made a breakthrough in building the nation in terms of guarding the nation's morality, including in the expulsion of Japanese colonialism who were members of PETA fighters (Saputra, 2016).

In fact, what has happened recently are many pesantren graduates who have not brought changes towards mastery of information technology which will result in a decrease in the human capital index that has lagged behind compared to other countries including ASEAN countries which are ranked 0.53 and occupy the position are 87 of 157 countries (Berita Satu, 2019; D'Souza et al., 2019). Most of the pesantren graduates still end up at a spiritual and moral level and have not been able to bring real change and control of science and technology, such as in the days of Bani Umayah and Bani Abbasiyah with the mastery of human civilization for 700 years. What was key at that time was progress in the fields of science and knowledge (Hafriza et al., 2018; Noor, 2015).

Even though Indonesia has a very large population in the world and has the potential for a demographic bonus (Mochlasin, 2018). This fact should be put to good use to increase human income per capita, increase people's welfare, and increase economic growth. The potential to become a world economic giant can be started from now from all sectors, especially in the field of education. Educational resources have a strategic role in forming the human capital index to increase in a planned manner. This research is considered necessary because it will describe the role of religious institutions or Islamic boarding schools, administrators, boarding school leaders for the students and all stakeholders in building human capital to develop fully human beings who have the ability in the spiritual field in one aspect and digitize mastery of information and technology in the next ten years.

Ecosystem control of technology and information transfer based on these divine spiritual values that will be needed, is not only limited to mastery of nanotechnology and robotics, but more than that is dexterity in the theological approach aspect. The dimensions of value and spirituality have begun to experience erosion and fading by internet technology (Maulana, 2018). The phenomenon of cyberreligion becomes evident when it has entered the realm of the general public and researchers suspect that many among the community, especially young people, use the media as a reference for their search for identity and guidelines. Among preachers or preachers, many use the internet as a religious reference (Khairuni, 2016). The transfer of digital technology to the quantum platform in the next 10 years will be realized in the cloud and big data.

How is the role of managers in developing and increasing the human capital index between its human resources and students for future competition? Can boarding school as Islamic scientific institutions adapt progress in the field of information technology coupled with their spiritual viscosity, what is the role of the pesantren leader or the pesantren manager who has full authority in educating his students to be able to adapt to long-term needs?

Researchers suspect that when pesantren opens up to new currents from the outside world, it is possible to become a dark horse in achieving the human capital index which has extraordinary advantages. The contribution of this research is that the role of Islamic boarding schools should receive serious attention in the development of the human capital index of human moral degradation which only relies on digitizing aspects of life by ignoring the norms, ethos and religious values that are helped, because human nature requires spiritual values that carry over since born (Audah, 
2015). Tarekah is an Islamic movement that focuses on approaching God through certain rites. There are many tarekat that have developed in Indonesia, one of which is the Idrisiyah Tarekat (Mardani, 2019)

The focus of this research is (1) Developing the potential of boarding school caregivers and leaders in forming a human capital index; (2) integrating Idrisiyah Islamic boarding school education with the spiritual aspects of its tarekat with the incorporation of information technology which will spur the digital economy. (3) the implications of the education of the These students are preparing their graduates or students to face a future in the next 20 years where it is estimated that mastery of technology and digitalization will still affect human life.

\section{Literature Review}

The problem that arises is that there is a disharmony of perspectives among the common people that the boarding schools with the tarekat sect tend to be traditional and only engage in ritual worship issues. Similar views are pinned on the students of this boarding school. The stigma that was built was that the students of the Tarekat Idrisiyah Islamic Boarding School were more inclusive and closed themselves off. The fact is not entirely true, researchers have conducted a related study about this boarding school that this boarding school is now more open to anyone who wants to study or become a member of this tarekat.(Mardani, 2019)

Nick Bontis (Bontis, 2014), regarding the human capital index that the high standard of living for intellectual power which can lead to high economic growth comes from high levels of health, high living standards and the involvement of international politics in the era of globalization. In this study, it is also illustrated that the newness of the HCI (Human Capital Index) in the future is strongly influenced by improvements in infrastructure and long-term investment. Finally, the attainment of knowledge acquired by a country can be beneficial for the global economic progress of that nation internationally or at least reginally. The most important thing in this research is that the development of human resources to strengthen the intellect of the HCI will provide better and more prosperous economic and financial welfare.

As happened in research in Saudi Arabia, this change cannot be taken into account except from the business sector. Including engaging two cross-border institutions in building the organization's intellectual strength, namely The Arab Knowledge Management Society (www.akms.org) and The Arab Club for Information (www.arabcin.org) (Bontis, 2014). Eko Wahyu Nugrahadi (Nugrahadi, 2018) in North Sumatra which is related to the HCI is influenced by per capita income, improving the quality of education and increasing healthy living standards. And also increasing the strength of human capital can also help increase the Human Development Index (HDI). He found that the impact of HCI (Human Capital Index) on HDI was 72.8\%. From this study, it is seen that a close relationship is that the increase in HCI (Human Capital Index) is highly correlated with HDI.

Gatti and Kathryn Andrews Ciro Avitabile Roberta (D'Souza et al., 2019) said that many countries are investing their human resources to increase the HCI, as well as for the health sector and social services. These three main factors will spur the fulfillment of a country's HCI. However, the biggest factor for government spending is dominated by the education sector and social security (Strategi \& Perusahaan, 2019). However, in developing countries, although spending in these three sectors is experiencing an upward trend, in fact the HCI value is weakening, this could be due to other factors that affect the HCI level to increase. Elena Pelinescu about the strategies applied in the European Union which focus on 3 factors in order to develop in a sustainable manner, namely skills, knowledge and values. However, these goals will be difficult to realize but by making way with the development of education and knowledge, good training can improve the country into a more developed country in a sustainable manner. Qiqi Yuliati Zaqiah (Zaqiah et al., 2019, p. 129) in this study he found that the role of character education is indispensable for the future. He saw that the teachers at the Islamic boarding schools provided more religious material according to the backgrounds of the teachers at the Islamic boarding schools, this correlated between the education the teachers received and the material being taught. He said that Islamic boarding schools are suitable and attractive media to develop norms of norms for their students. Implementation of this model requires support from various parties such as the board of pesantren managers, parents, students, government and the community(Mensi et al., 2019; Nafukho et al., 2004; Roncancio R, Ginna \& Sáenz G, 2016).

Gerhards (Gerhards \& Silke Hans, 2013) said that what can generate the HCI value is proficiency in foreign languages 
and intellectual competence. He assessed that exchanges between foreign students or students can stimulate the growth of the $\mathrm{HCI}$ or researchers considering human investment, as the basic capital for the development of the HCI. With the help of literature on the sociology of education and the work of Pierre Bourdieu, he has developed a hypothesis and tested it using data from the German Socio-Economic Panel (GSOEP). His findings suggest that the likelihood of studying abroad is determined a) by parental-driven capital, b) by cultural capital and children's own commitment, c) by structured opportunity (encouragement from the government) and d) by family conflict. The presence of the Gymnasium has an important filtering function. Overall, the possibility of obtaining transnational human resources can be obtained by increasing children's intellectual power which is driven by the child's family economy.

\section{Methods}

This research uses qualitative research with a phenomenological approach (Mardani, 2016; "Methodology for a World Bank Human Capital Index," 2018). Data collection techniques through documentation studies, interviews and observations. Observations made by this researcher were to visit directly to the object of research, namely the Islamic boarding school Tarekat Idrisiyah, both in the learning process and towards the leaders and teachers. Interviews were conducted with resource persons consisting of boarding school leaders, teaching staff, and clinical officers who were related to the health level of the residents of this Islamic boarding school. Documentation studies were carried out with various people who have relevant information including data on the learning history of the students, the number of achievements that have been achieved, the consequences of worship, religious activities, the number of criminals in the Islamic boarding school, the number of sick students and others. Miles and Huberman's qualitative analysis techniques consist of: 1) data completion, 2) data editing, and 3) drawing conclusions and verification. As stated by Saepudin (Saepudin, 2019), data reduction is the stage in selecting, focusing and simplifying, abstracting and transforming data that arise in the interview document.

\section{Result and Discussions}

There is a prolonged gap (Indonesia Invesment, 2019), where Indonesia, which has been 77 years of independence with Indonesia's GDP since 2000, has fluctuated, but tends to keep increasing, based on the percentage or aggregate of total income per capita but the budget for education has increased over the years. 2016 (Sharma, et.al. 2016). As shown in table 1.

Tabel 1 Gross Domestic Growth (GDP) Statistics:

\begin{tabular}{lc}
\hline & Average GDP Growth $(\%)$ \\
\hline $1998-1999$ & -6.65 \\
$2000-2004$ & 4.60 \\
$2005-2009$ & 5.62 \\
$2010-2015$ & 5.63 \\
$2016-2017$ & 5.05 \\
\hline
\end{tabular}

Tabel 2 The base year for computing the economic growth rate shifted from 2000 to 2010 in 2014, previous years have been recalculated

\begin{tabular}{crrrrrr}
\hline & 2007 & 2008 & 2009 & 2010 & 2011 & 2012 \\
\hline GDP (in billion USD) & 432.2 & 510.2 & 539.6 & 755.0 & 893.0 & 918.0 \\
GDP (annual\% change) & 6.3 & 6.0 & 4.6 & 6.2 & 6.2 & 6.0 \\
GDP (annual\% change) & 1.861 & 2.168 & 2.263 & 3.167 & 3.688 & 3.741 \\
\hline
\end{tabular}




\begin{tabular}{crrrrrr}
\hline & 2013 & 2014 & 2015 & 2016 & 2017 & 2018 \\
\hline GDP (in billion USD) & 915.0 & 891.0 & 861.0 & 933.0 & & \\
GDP (annual\% change) & 5.6 & 5.0 & 4.9 & 5.0 & 5.1 & 5.17 \\
GDP (annual\% change) & 3,528 & 3,442 & 3,329 & 3,603 & & \\
\hline Source: World Bank & & & &
\end{tabular}

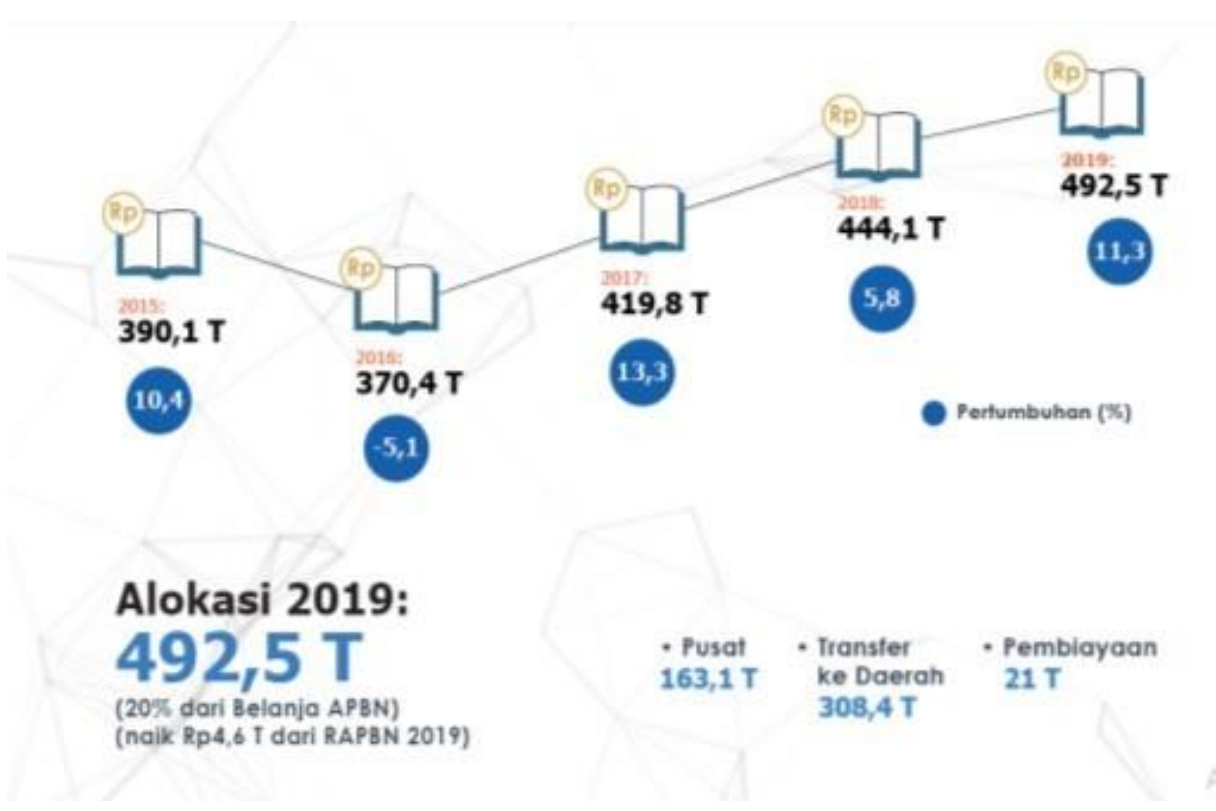

Fig. 1 Allocation of Indonesian Education Funds Source: RI Ministry of Finance 2019

This gap, researchers suspect that the use of the budget for improving the quality of human resources is not in the proposition, but rather for the development of school infrastructure, and the lack of students who receive scholarships from the Education Fund Management Institution (LPDP) endowment fund to continue their education to advanced or tertiary levels. Universities that offer study programs for PBSB (Scholarship Program for Achieving Santri) are dominated by universities with religious study programs, while for science and technology there are only 2 universities (Ministry of Religius, 2020). So that the fuse and dimensions of Indonesia's human capital index have not increased compared to other countries in Southeast Asia, especially on a larger scale.

Researchers develop a program and paradigm about changes in a community or a country, so what must be immediately addressed is related to human resources. An increase in human resources is absolutely necessary to boost the transport of a country, starting with the increase in HCI, especially in the science and internet technology sector, which must get a large enough portion, because the challenges in the next 30 years will depend on big data and be connected to all. humans with the internet.

Besides that, generically, humans need spiritual and moral discipline. In this research, the Islamic boarding school tarekat Idrisiyah has made a tradition of spiritual strengthening and a transcendent attitude towards the sheikh Akbar or murshid of the boarding school. The researcher uses the Charismatic theory by Max Weber, where the Tarekat boarding school is controlled by the Murshid or spiritual leader who has special characteristics such as the number of followers, in terms of clothing, many transformations in the future (Mardani, 2019). The murshid always provides directions and advice on where this boarding school should go, what should be done in the future and in part (Mardani, 2019). 
According to Weber (McCulloch, 2014) leaders who have charisma tend to have many followers. In language, charisma means a special gift or ability. Whereas in the popular dictionary that charisma is when someone has the authority and excess that is obtained from God. Dodd (2005) with the characteristics of appearing at a critical time, having charismatic power, appearing when the time is needed, he able to overcome problems that people think are impossible to solve or solve, at least the individual crisis felt by his followers. has charm either from his physical appearance or personality and is believed by his followers. His followers are the basis of his strength, it is impossible for him to fight alone. And the last one he can prove his ideas and ideas he can make rules and regulations according to what he wants are not bound by juridical normative. This charismatic level is obtained from personal minning, the second is inheritance or affilition is then built by the nature of altruism.

Weber defines charisma as a social phenomenon that appears at certain times and in certain dynamics, besides that he also has a fanatical following towards himself. In other words, according to Weber charisma is a trait inherent in a leader as if he has been given a special task and has special talents by God to lead a group of humans. often use racinality in taking action. Instrumental rationale is the conformity of action with the result (instrumental rational), which is both value-oriented rational action, which is based on religious values and doctrines from the Divine. There is an institution of values that must be followed, why does it think, this is taught from religious propositions (Kalemci \& Kalemci Tuzun, 2019)

The third is traditional actions that are assumed to be the customs of society in general. And the last is affective action is an action that is born because of the impulse of feeling. Another aspect that has a stronger dimension in the implementation of business units that developed rapidly during the leadership of Murshid Syekh Faturahman, which was more precisely when he led this pondok, even though his election was based on lineage or lineage although connected to the prophet Muhammad (Mardani, 2019).

His theory is that business is a necessity and obligation of Muslims. Islam must advance, not only as a spectator, but must enter the playing field of business people and the concept is successful at least for the economic sector, besides that there are many other aspects. According to researchers this is an extraordinary achievement. In the application of this cottage business using approch theology, or the divine approach. The method of understanding and giving direction to humans or their students must have a different approach from the machine or object approach, this is called the Verstehen method (Mustafa, 2011). He said that there is something that has extraordinary sight and hearing above humans. Because humans are dynamic in nature so it cannot be explained in detail what events will occur, this is different from goods or machines that are measured and easily conceptualized for the movement of movements that will occur at least knowing from the user guide. The theory in the middle is the theory of educational disruption. The theory taken is from Clayton M. Christensen (Christensen et al., 2008) said that if schools do not experience innovation and change, they will be destroyed or left behind, he described it in figure 2.

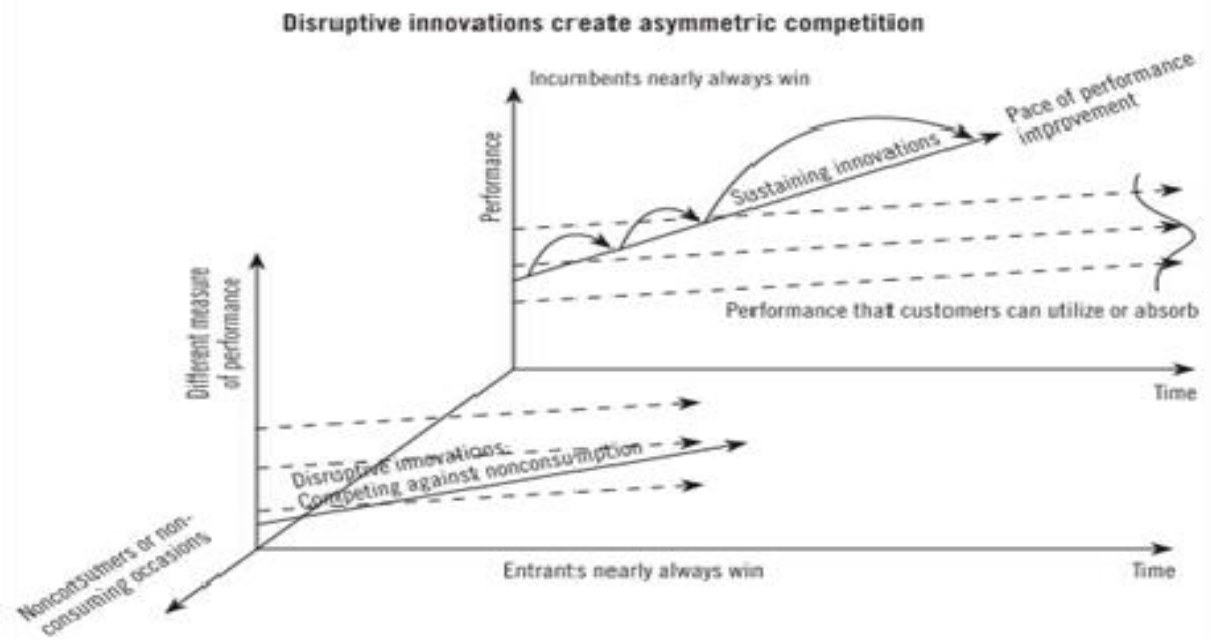

Fig. 2 Educational Disruption Model 
From this figure it can be explained that the theory of innovation innovation assumes that an organization will succeed with innovation. In this picture, it shows that if a company keeps doing products from time to time it will receive revenue that increases little by little. The straight line illustrates the steps of improvement that companies provide to their customers by introducing new and better products and services.

Meanwhile, the dotted line shows the level of performance improvement that customers can take advantage of. As these intersecting lines suggest, customer needs in certain market applications tend to be relatively stable over time, but companies usually upgrade their products at a much faster rate than customers need resulting in products, which at one point were not good enough, in the end it packs more features and functionality than customers can use. This is called innovation that encourages companies to continue to innovate. As in the picture above.

Some dramatic breakthroughs were made, while others were running a business regularly (bussines as usaul) there was no change, and this company's innovation had a disruptive impact on the company and from outside the company. In his research he has found that in almost every case, the company that wins the battle for innovation is already the industry leader. And it doesn't seem to matter how big the technological challenge is to innovate. As long as it helps leaders make better products that they can sell for a better profit to their best customers, they look for ways to solve them (Christensen et al., 2008).

Although his theory was at odds with Clayton M. Christensen's, Francis Fukuyama (Fukuyama, 1999) has a different view regarding the Distortion Theory, he believes that there is a tendency for an increased crime rate, increased violence caused by family factors. Household leaders are not close to their children. This is due to the busyness of each (playing and playing technology), that changes and ways of conveying messages and opinions are so fast with technology. He worries that the rapid development of technology will reduce the feeling and closeness of the family to be reduced. Thanks to technology that was originally far from being close, which was difficult to become easy, there was social interaction in cyberspace. He also said that humans tend to show that outwardly humans are social and political creatures, and not isolated and selfish individuals. But human sociability is not a type of altruism that is not different from other people. Even when humans have a special ability to cooperate and create social capital, they do so in a way that protects their interests as individuals.

Consequences of Family Disruption The decline in the nuclear family in the West has a very large negative impact on social capital and is associated with increased poverty for people under social hierarchies, increased crime rates, and ultimately decreased trust. One of the most important consequences of a decrease in social capital in the family is a decrease in human capital of the next generation. Most of the decline in test scores that occurred in the United States during the Great Disruption period can occur at the doorsteps of disturbed, disturbed, poor families (Fukuyama, 2006).

The second problem is that family breakdown is itself a cause of poverty. A number of studies have shown what common sense would assume: households with only one parent lose economies of scale, withdraw only half of their income, labor, and social capital from those with two, and stop benefiting from the division of labor between two parents.

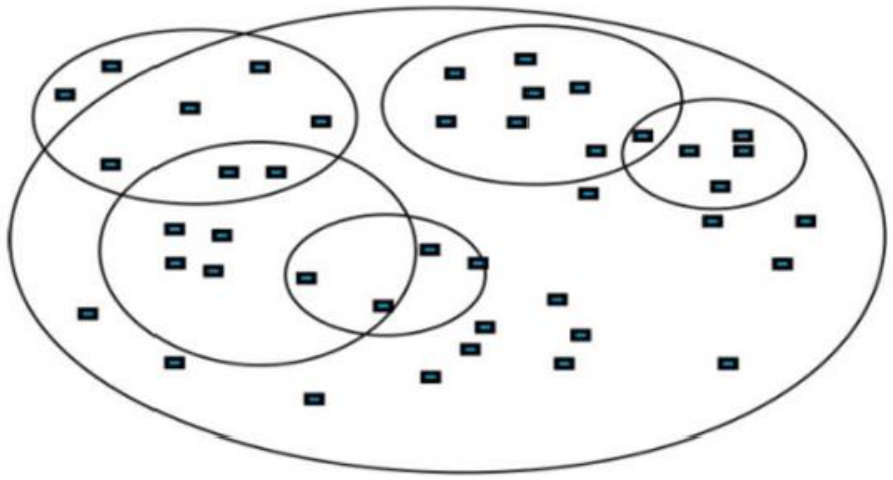

Fig. 3 Relations between groups and individuals 
The following figure shows that the network differs from the market insofar as the network is defined by shared norms and values. It describes the economic cycle in a network with various variants of an economic transaction. Transactions in a market like it or not will require norms and values and agreement between all groups, but in fact, economic norms are not as broad as social relations norms. Communication using a different language, initially at the Tarekat Idrisyah Islamic boarding school also happened this way, where there was assimilation in the languages of various regions, the situation was furious because the pondok authorities gave the same rules to all students (Damsaz \& Andrabi, 2016).

The Huaman Capital Index has recently been coined by Theodore William Schultz, he said that the HCI is a factor that can increase a country's economic productivity. Logical ways to achieve HCI include: 1) Human as human resources, seen from the number, which means that how much the number of human resources will be more productive, especially if the number of people who meet the indexation will increase the quality of a country's income. 2) Investing in increasing education and training. This is an indication that people who have education and skills will increase their productivity. And this second method does not require a volume level of labor (Golley \& Meng, 2011).

Meanwhile, according to Todaro that improvement can be achieved with the HCI through education and health (Todaro \& Smith, 2011). Education and training will add value to human capital, this will be proven if a person's high education and training will improve skills. This will be the same as the level of health, because humans will be free to think and work if they have a high level of health. And will increase the value of productivity when he works (Todaro \& Smith, 2011). High education can improve a healthier life attitude, health can increase the level of health as measured by Life Expectancy (AHH). AA value is obtained by the amount of time that a person has passed during his life. (Efendi et al., 2019). The higher the life expectancy, the higher the health. In the field of education, it has a hierarchy and levels of education from elementary to tertiary education (Nafukho, Hairston and Brooks, 2004). Formal and non-formal education, including in the workplace (Savvides \& Stengos, 2019) as well as on-the-job training and apprenticeship (Nafukho et al., 2004) and tiered education at a special vocational level at the middle and high levels, which will have implications for economic development (Nafukho et al., 2004).

According to Ritika D'Souza (D'Souza et al., 2019, p. 6). Education itself has 3 components, namely: Component 1 is survival from birth to school age, measured using the infant mortality rate. Component 2, Length of study in school according to expected years, incorporating information about the amount and quality of education. Component 3 , is health, which can be identified by: (i) the adult survival rate, defined as the fraction of children aged 15 who survive to age 60, and (ii) the stunting rate for children under 5 years of age. Adult survival rate can be interpreted as a representation and description of the various fatal and non-fatal health outcomes experienced by children born today as adults if current conditions prevail in the future). The implication of this theory is that if all stakeholders use this theory, it will increase the implications of the increase in HCI, starting from the leadership, managers, teaching staff and all students. The relationship between the theoretical teroi stated above and the research research that has been described above shows a very close relationship. Starting from the epistemological point of view related to the increase in $\mathrm{HCI}$ and the axiology implications of the achievements of the theory.

The findings stated above have been used by some researchers only in the macro form, namely the country. However, currently the researcher will link this theory to the small community, namely the Islamic boarding school. He found that intellectual factors can make a country more advanced and able to boost economic growth (Pepinsky, 2013; Schecter, 2007; UN ESCAP, 2018). The debate or hypothesis that there must be collabiration from state institutions or NGOs in making these ideals, is ensured not only by government agencies that move but all units must work hand in hand in increasing intellectual property and the HCI.

\section{Conclusions}

The human capital index has a big role in building human resources. Human resource development is not sufficient with three aspects, namely health, education and social security. Researchers found that there are aspects of theology and religion that can encourage human prosperity not only material, apart from that it is happiness in the world and in the last day. 


\section{References}

Audah, A. (2015). Bahasa Agama Dalam Wacana Sosiologi Agama. 11, 67-79.

Bahri, S. (2018). Peran Pondok Pesantren dalam Mencegah Paham Radikalisme di Kabupaten Rejang Lebong. KAGANGA: Jurnal Pendidikan Sejarah Dan Riset Sosial-Humaniora, 1(2), 107-121. DOI: 10.31539/kaganga.v1i2.483

Berita Satu. (2019). Human Capital Index Indonesia Tertinggal Jauh dari ASEAN. https://www.youtube.com/watch?v=Wao6gKRxD_0

Clayton M. Christensen, Horn, M. b., \& Johnson, C. w. (2008). Disrupting Class How Disruptive Innovation Will Change the Way the World Learns (Clayton M. Christensen (ed.)). McGraw-Hil. DOI: 10.1036/0071592067

D'Souza, R., Gatti, R., \& Kraay, A. (2019). A Socioeconomic Disaggregation of the World Bank Human Capital Index (Issue September). http://www.worldbank.org/prwp

Damsaz, S., \& Andrabi, A. (2016). Message of Peace Through Sufism. 2016, 1-4.

Dillon, M. (2009). The Sociology of Religion. The New Blackwell Companion to Social Theory, 409-427. DOI: 10.1002/9781444304992.ch21

Dodd, S. D. (2005). An Examination of The Inter-Relationships Between Entrepreneurship And Religion. the Robert Gordon University and Aberdeen Business School.

Efendi, M. H., Irawati, M. H., Rohman, F., Gofur, A., Biologi, P., \& Negeri, U. (2019). Model pendidikan konservasi lingkungan hidup dengan penerapan nilai-nilai islam di pondok pesantren nurul haramain nw narmada lombok barat - indonesia. 6(1), 40-48.

Fukuyama, F. (2006). America at the Crossroads: Democracy, power, and the neoconservative legacy. America at the Crossroads: Democracy, Power, and the Neoconservative Legacy, 1-226. https://doi.org/10.2307/20031939

Fukuyama, F. (1999). The great disruption: human nature and the reconstitution of social order $\left(1^{\text {st }}\right.$ ed.). New York: The Free Press.

Gerhards, J., \& Hans, S. (2013). Transnational human capital, education, and social inequality. Analyses of international student exchange. Zeitschrift für Soziologie, 42(2), 99-117.

Golley, J., \& Meng, X. (2011). China Economic Review Has China run out of surplus labour? China Economic Review, 22(4), 555-572. DOI: 10.1016/j.chieco.2011.07.006

Hafriza, R. H., M.H, F., \& Chuzairi, A. (2018). Manajemen Zakat Sebagai Penyeimbang Perekonomian Umat. Perada, 1(1), 45-58. DOI: 10.35961/perada.v1i1.6

Ilyas, M., Sibuea, A. M., \& Zahrila. (2019). Leadership transformation; study of islamic boarding school (DAYAH) in Aceh Province Of Indonesia. Journal of Entrepreneurship Education, 22(2), 1-5.

Indonesia Invesment. (2019). Produk Domestik Bruto Indonesia. https://www.indonesiainvestments.com/id/keuangan/angka-ekonomi-makro/produk-domestik-bruto-indonesia/item253

Jahar, A. S. (2015). Transformasi Gerakan Ekonomi Islam Kontemporer. MIQOT: Jurnal Ilmu-ilmu Keislaman, $39(2)$.

Kalemci, R. A., \& Kalemci Tuzun, I. (2019). Understanding Protestant and Islamic Work Ethic Studies: A Content Analysis of Articles. Journal of Business Ethics, 158(4), 999-1008. DOI: 10.1007/s10551-017-3716-y

Kementerian Agama. (2020). Statistik Data Pondok Pesantren. Pangkalan Data Pondok Pesantren. https://ditpdpontren.kemenag.go.id/pdpp/statistik?id=32

Khairuni, N. (2016). Dampak Positif Dan Negatif Sosial Media Terhadap Pendidikan Akhlak Anak. Edukasi, 2, 91106. 
Manan, M. A. (2019). Daya Tahan dan Eksistensi Pesantren Di Era 4.0. Jurnal Pendidikan Islam Indonesia, 3(2), 301-313. DOI: 10.35316/jpii.v3i2.135

Mardani, D A. (2019). Spritual Entrepreneurship Dalam Pemberdayaan Ekonomi Umat. Al Amwal (Hukum Ekonomi Syariah), 2(1), 37-44.

Mardani, D. A. (2016). Peran Perbankan Syariah Dalam Mengimplementasikan Keuangan Inklusif di Indonesia. Alafkar, 14(2), 105-120. DOI: 10.15408/etk.v14i2.2272

Mardani, D. A. (2019). Spritual Entepreneurship Dalam Pemberdayaan Ekonomi Umat: Studi Terhadap Tarekat Idrisiyah Pageningan Tasikmalaya. Al-Afkar, Journal For Islamic Studies, 2(2, July), 194-206.

Mardani, D. A. (2019). Spritual Entepreneurship Dalam Pemberdayaan Ekonomi Umat (Studi terhadap Tarekat Idrisiyah Pageningan Tasikmalaya). Al-Afkar, Journal For Islamic Studies, 4(1).

Maulana, H. (2018). Media Sosial, Sumber keberagamaan Alternatif Remaja. 22(1), 1-34.

McCulloch, A. D. (2014). Charisma and patronage: Reasoning with Max Weber. In A. d McCulloch (Ed.), Charisma and Patronage: Reasoning with Max Weber. Ashgate Publishing Limited. www.ashgate.com

Mensi, W., Hammoudeh, S., Tiwari, A. K., \& Al-Yahyaee, K. H. (2019). Impact of Islamic banking development and major macroeconomic variables on economic growth for Islamic countries: Evidence from panel smooth transition models. Economic Systems, 100739. DOI: 10.1016/j.ecosys.2019.100739

Methodology for a World Bank Human Capital Index. (2018). In Policy Research Working Papers. The World Bank. DOI:10.1596/1813-9450-8593

Mochlasin. (2018). Zakat Untuk Mengurangi Angka Ketergantungan Ekonomi Dengan Penyaluran Model Usaha Produktif. Jurnal Penelitian Sosial Keagamaan, 12(1), 239-258.

Noor, M. S. (2014). Prospek Ekonomi Syariah di Tengah Persaingan Ekonomi ASEAN. Islamiconomic: Jurnal Ekonomi Islam, 5(2).

Mustafa, M. (2011). Agama dan bayang-bayang etis Syaikh Yusuf al-Makassari. Yogyakarta: LKIS Pelangi Aksara.

Nafukho, F. M. capital theory: I. for human resource development, Hairston, N. R., \& Brooks, K. (2004). Human capital theory: Implications for human resource development. Human Resource Development International, 7(4), 545-551. DOI: 10.1080/1367886042000299843

Nugrahadi, E. W. (2018). Analysis of Human Development Index: Concept and Factors that Influence North Sumatera Province. 46(Ebic 2017), 27-31.

Pepinsky, T. B. (2013). Development, Social Change, and Islamic Finance in Contemporary Indonesia. World Development, 41, 157-167. DOI: 10.1016/j.worlddev.2012.06.007

Roncancio R, Ginna \& Sáenz G, C. (2016). Digital Society Key Initiatives. IOSR Journal of Economics and Finance, 3(1), 56. DOI: $10.3929 /$ ethz-b-000238666

Saepudin, J. (2019). Pendidikan Agama Islam Pada Sekolah Berbasis Pesantren : Studi Kasus Pada Smp Al Muttaqin Kota Tasikmalaya. EDUKASI: Jurnal Penelitian Pendidikan Agama Dan Keagamaan, 17(2), 172-187. DOI: 10.32729/edukasi.v17i2.559

Saputra, E. (2016). Dampak Sosial Media Terhadap Sikap Keberagamaan Remaja Dan Solusinya Melalui Pendidikan Agama Islam. Sosio e-kons, 8(2), 160-168.

Savvides, A., \& Stengos, T. (2019). Human Capital and Economic Growth. In Journal of Chemical Information and Modeling, 53(9). DOI: 10.1017/CBO9781107415324.004

Schecter, D. (2007). Liberalisms and the limits of knowledge and freedom: On the epistemological and social bases of negative liberty. History of European Ideas, 33, 195-211. DOI: 10.1016/j.histeuroideas.2006.11.005 
Sharma, R. R., Newaz, F. T., \& Fam, K. S. (2017). Muslim religiosity, generational cohorts and buying behaviour of Islamic financial products. Australian Journal of Management, 42(3), 482-501. DOI: $10.1177 / 0312896216659530$

Smith, C. (Ed.). (2014). Disruptive religion: The force of faith in social movement activism. Routledge.

Todaro, M., \& Smith, S. C. (2011). Chapter 5: Poverty, Inequality and Development. In Economic Development. UN ESCAP. (2018). Digital and Virtual Currencies for sustainable Development.

Ying, Z., Liu, S., Bao, S., \& Zhou, J. (2017). China Economic Review Religious diversity and regional development in China. China Economic Review, 46(August), 1-9. DOI: 10.1016/j.chieco.2017.08.003

Zaqiah, Q. Y., Hasanah, A., Heryati, Y., \& Gunawan, H. (2019). The Model of Cultivating National Character Values in an Islamic Boarding School (Pesantren). 253(Aes 2018), 129-133. DOI: 10.2991/aes-18.2019.31 